\title{
Association between mutations of the luteinizing hormone $\beta$ subunit and female infertility
}

\author{
JIU-WEI DU, KE-YI XU, LI-YI FANG and XIN-LAN QI \\ School of Medicine, Anhui University of Science and Technology, Huainan, Anhui 232001, P.R. China
}

Received August 24, 2011; Accepted November 4, 2011

DOI: $10.3892 / \mathrm{mmr} .2011 .683$

\begin{abstract}
To explore the association between mutations of Trp8Arg and Ile15Thr in the luteinizing hormone (LH) gene and female infertility, primary female infertility patients $(n=60)$ and normal healthy women $(n=60)$ were screened for mutations Trp8Arg and Ile15Thr in the LH- $\beta$ subunit gene by polymerase chain reaction-restriction fragment length polymorphism, and associations were examined between the mutations and female infertility. The results showed that there were significant differences in the allele and genotype frequencies of Trp8Arg and Ile15Thr between the two groups $(\mathrm{P}<0.05)$. A significant difference was noted in the LH level among women with different genotypes $(\mathrm{P}<0.05)$, and the LH level was highest in women who were homozygous for both mutations. However, there were no significant differences in FSH level and FSH/LH ratio among subjects with different genotypes $(\mathrm{P}>0.05)$. In conclusion, polymorphisms of Trp8Arg and Ile15Thr in the LH- $\beta$ subunit gene occur in infertile women. The polymorphisms correlate with female infertility and may be a risk factor in the pathogenesis of female infertility.
\end{abstract}

\section{Introduction}

Infertility is a worldwide medical and social problem, currently occurring in 10-15\% of married couples (1). The causes of female infertility are complicated and have various influencing factors, including genetic factors (2). Luteinizing hormone ( $\mathrm{LH})$ plays a crucial role in the growth and development of follicles, and genetic mutations in LH may affect its biological function (3). Currently, two point mutations (Trp8Arg and Ile15Thr) in the gene encoding the LH- $\beta$ subunit have been described. However, there is limited knowledge on the relationship between these mutations and infertility. In this study, the relationship between mutations of Trp8Arg and Ile15Thr of the LH- $\beta$ subunit and infertility is examined.

Correspondence to: Dr Jiu-Wei Du, School of Medicine, Anhui University of Science and Technology, Dongshanzhong Road 25, Huainan, Anhui 232001, P.R. China

E-mail: djwdxswy@126.com

Key words: female infertility, luteinizing hormone, gene mutation

\section{Materials and methods}

Experimental subjects. Subjects included female patients $(n=60)$ aged 24-42 years, with a mean age of $31.35( \pm 3.59)$ years with primary infertility treated at the Affiliated Hospital, School of Medicine, Anhui University of Science and Technology, from July 2009 to July 2011. Healthy women $(n=60)$ aged 24-39 years, with a mean age of $30.50( \pm 3.29)$ years with normal physical examinations were selected as the control group during the same time period. The inclusion criteria for subjects in the treatment group were abnormal menstrual cycle, an LH level above the normal range, no concomitant medical diseases, such as diabetes, tuberculosis, endocrine diseases (thyroid, adrenal gland), recent surgical diseases and congenital diseases, and no hormone therapy in the last 3 months prior to enrollment. The inclusion criteria for healthy women in the control group were previous pregnancy, normal menstrual flow and cycles, normal LH levels, no hormone therapy in the last 3 months prior to enrollment and no recent surgical or medical diseases. There was no significant difference in ages between the two groups $(\mathrm{P}>0.05)$. Patient consent was obtained by all patients. Approval was obtained by the Ethics Committee of School of Medicine, Anhui University of Science and Technology.

\section{Experimental methods}

DNA extraction. Peripheral venous blood $(2 \mathrm{ml})$ was taken from each subject in the morning in a fasted state and placed in sterile EDTA tubes. Genomic DNA was extracted using DNA extraction kits (Takara Biotech, Dalian, China). Extracted DNA was quantified by the ultraviolet spectrophotometric method and then maintained at $-20^{\circ} \mathrm{C}$ for later use.

Primer design and synthesis. Tpr8Agr and Ile15Thr mutations are both located in the 2 nd exon of the LH- $\beta$ subunit gene that has an amplified fragment length of $660 \mathrm{bp}$. The primers were designed according to the literature $(4,5)$, with an oligonucleotide primer sequence of sense 5'-AGTCTGAGACCTGTGGGGTCAGCTT-3' and antisense 5'-GGAGGATCCGGGTGTCAGGGCTCCA-3'. The primers were synthesized by Takara Biotech.

PCR amplification. The total PCR reaction volume was $50 \mu 1$ and included $5.0 \mu \mathrm{l}$ of $10 \mathrm{X}$ buffer $\left(15 \mathrm{mM} \mathrm{MgCl} \mathrm{Mg}_{2}\right), 4.0 \mu \mathrm{l}$ of $\operatorname{dNTP}(200 \mu \mathrm{mnol} / \mathrm{l}), 1.0 \mu \mathrm{l}$ of each primer $(25 \mathrm{pmol} / \mu \mathrm{l}), 0.5 \mu \mathrm{l}$ 
of TaqDNA polymerase $(5 \mathrm{U} / \mu 1)$ and $4 \mu 1$ of DNA template. Deionized water was added for a total volume of $50 \mu 1$.

Reaction conditions were $94^{\circ} \mathrm{C}$ for $5 \mathrm{~min}$ of denaturation, and 32 cycles of $94^{\circ} \mathrm{C}$ for $30 \mathrm{sec}$ of denaturation; $60^{\circ} \mathrm{C}$ for $1 \mathrm{~min}$ of annealing and $72^{\circ} \mathrm{C}$ for $2 \mathrm{~min}$ of extension. PCR amplification success was determined by electrophoresis with a $2 \%$ agarose gel containing $0.5 \mathrm{mg} / \mathrm{ml}$ ethidium bromide. Bands were visualized with ultraviolet light and photographed with the Gel Doc1000 UV gel-imaging system (Bio-Rad).

Analysis of restrictive fragment length polymorphism $N c o I$ endonuclease and ForkI endonuclease (10 U/ $\mu$ l; NEB Corporation) were used for enzymatic digestion. Reactions were carried out in a total volume of 20:10 $\mu \mathrm{l}$ of PCR product, $2.5 \mu \mathrm{l}$ of $10 \mathrm{X}$ buffer, $2 \mu \mathrm{l}$ of endonuclease and water to $20 \mu \mathrm{l}$. The reaction was mixed evenly and placed in a $65^{\circ} \mathrm{C}$ water bath and digested for $4 \mathrm{~h}$. Fragmentation was determined by electrophoresis with a $2 \%$ agarose gel (containing $0.5 \mathrm{mg} / \mathrm{ml}$ ethidium bromide). Bands were visualized with ultraviolet light and photographed with the Gel Doc1000 UV gel-imaging system.

Sequence determination of the DNA sequences of the PCR product was carried out using ABI PRISM ${ }^{\mathrm{TM}}$ 377XL DNA Sequencer (Takara Biotech).

Statistical analysis. SPSS13.0 software was used to process the data. Mean \pm standard deviation was used to express the measured data. The $\chi^{2}$ test was used to analyze the gene allele and genotype frequencies of the mutations of the LH- $\beta$ subunit between the two groups. Single-factor analysis of variance was applied to compare LH, FSH and FSH/LH ratios of women with different genotypes. Within-group pairwise comparisons were conducted using Student-Newman-Keuls (SNK). The tests were two-sided with a test level $(\alpha)$ of 0.05 , and a P-value $<0.05$ was considered to denote statistical significance.

\section{Results}

Results of electrophoresis and sequencing. The amplified fragment length of the LH- $\beta$ subunit gene was $660 \mathrm{bp}$. For PCR products digested through NocI, the normal wild-type (Tpr/Tpr-type) showed three bands of 475, 100 and $85 \mathrm{bp}$. The Tpr8Agr mutation homozygote (Arg/Arg-type) showed two bands of 475 and $185 \mathrm{bp}$. The Tpr8Agr mutation heterozygote (Arg/Tpr-type) showed four bands of 475, 185, 100 and $85 \mathrm{bp}$ (Fig. 1). For PCR products digested with ForkI, the normal wild-type (Ile/Ile-type) showed four bands of 390, 176, 51 and $43 \mathrm{bp}$. The Ilel5Thr mutation homozygote (Thr/Thr-type) showed three bands of 433, 176 and $51 \mathrm{bp}$. The Ilel5Thr mutation heterozygote (Thr/Ile-type) showed five bands of 433, 390, 176, 51 and 43 bp (Fig. 2).

Results of the RFLP analysis. Of the 120 subjects, 100 (83.3\%) were normal wild-type (Trp/Trp-type) for the Trp8Arg mutational genotype, 15 (12.5\%) were mutation homozygotes (Arg/ Arg-type), and 5 (4.2\%) were mutation heterozygotes (Arg/ Trp-type). The Trp allele frequency was $89.6 \%$ and the Arg allele frequency was $10.4 \%$. There was a statistically significant difference in genotype and allele frequencies between the two groups $(\mathrm{P}<0.05)$, as shown in Table I.

Of the 120 subjects, $103(85.8 \%)$ were normal wild-type (Ile/Ile type) for the Ile15Thr mutation, 14 (11.7\%) were muta-

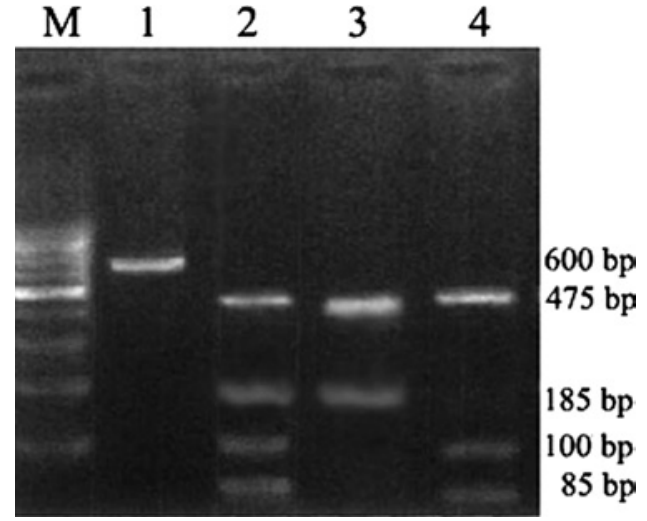

Figure 1. Electrophoretogram of the Trp8Arg mutation in the LH- $\beta$ subunit. Lane M, DNA marker; lane 1, PCR product; lane 2, mutation heterozygote; lane 3 , mutation homozygote; lane 4 , normal wild-type.

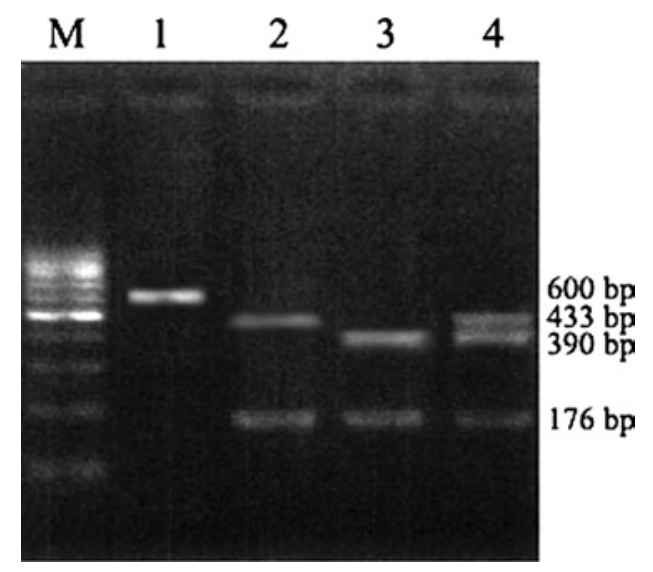

Figure 2. Electrophoretogram of the Ile15Thr mutation in the LH- $\beta$ subunit. Lane M, DNA marker; lane 1, PCR product; lane 2, mutation homozygote; lane 3, normal wild-type; lane 4, mutation heterozygote.

tion homozygotes (Ile/Thr-type), and 3 (2.5\%) were mutation heterozygotes (Thr/Thr-type). The Ile allele frequency was $91.7 \%$ and the Thr allele frequency was $8.3 \%$. There was a statistically significant difference in genotypes and allele frequencies between the two groups $(\mathrm{P}<0.05)$, as shown in Table II.

FSH, LH and FSH/LH ratio as related to genotype. Tables III and IV show that the LH levels were significantly different among the different genotypes $(\mathrm{P}<0.05)$, while FSH levels and $\mathrm{FSH} / \mathrm{LH}$ ratios were not significantly different $(\mathrm{P}>0.05)$. Compared to the normal wild-type, subjects with a homozygous mutation had significantly higher LH levels $(\mathrm{P}<0.05)$.

\section{Discussion}

LH is a gonadotropin secreted by the anterior pituitary under stimulation of hypothalamic gonadotropin. LH plays a crucial role in estrogen synthesis and ovum maturation (6). LH belongs to a glycoprotein family that shares a common $\alpha$ subunit yet contains a unique $\beta$ subunit (7). The $\alpha$ subunit varies in individuals of different ethnic race, yet is not related with antigenicity and levels of LH. While the $\beta$ subunit 
Table I. Genotype and allele frequencies of the Trp8Arg mutation in the LH- $\beta$ subunit between the two groups [n (\%)].

\begin{tabular}{lrrrrrr} 
& & \multicolumn{3}{c}{ Genotype frequency $^{\mathrm{a}}$} & & \multicolumn{2}{c}{ Allele frequency $^{\mathrm{b}}$} \\
\cline { 3 - 5 } Group & $\mathrm{n}$ & Trp/Trp & Trp/Arg & Arg/Arg & Trp & Arg \\
\hline Study group & 60 & $45(75.0)$ & $11(18.3)$ & $4(6.7)$ & $101(84.2)$ & $19(15.8)$ \\
Control group & 60 & $55(91.7)$ & $4(6.7)$ & $1(1.7)$ & $6(5.0)$ \\
Total & 120 & $100(83.3)$ & $15(12.5)$ & $5(4.2)$ & $215(89.6)$ & $25(10.4)$
\end{tabular}

${ }^{\mathrm{a}} \chi^{2}=6.067, \mathrm{P}=0.048 ;{ }^{\mathrm{b}} \chi^{2}=7.546, \mathrm{P}=0.006$

Table II. Genotype and allele frequencies of the Ile15Thr mutation in the LH- $\beta$ subunit between the two groups [n (\%)].

\begin{tabular}{|c|c|c|c|c|c|c|}
\hline \multirow[b]{2}{*}{ Group } & \multirow[b]{2}{*}{$\mathrm{n}$} & \multicolumn{3}{|c|}{ Genotype frequency $^{\mathrm{a}}$} & \multicolumn{2}{|c|}{ Allele frequency ${ }^{\mathrm{b}}$} \\
\hline & & Ile/Ile & Ile/Thr & Thr/Thr & Ile & Thr \\
\hline Study group & 60 & $47(78.3)$ & $10(16.7)$ & $3(5.0)$ & $104(86.7)$ & $16(13.3)$ \\
\hline Control group & 60 & $56(93.3)$ & $4 \quad(6.7)$ & $0(0.0)$ & $116(96.7)$ & $4 \quad(3.3)$ \\
\hline Total & 120 & $103(85.8)$ & $14(11.7)$ & $3(2.5)$ & $220(91.7)$ & $20 \quad(8.3)$ \\
\hline
\end{tabular}

${ }^{\mathrm{a}} \chi^{2}=6.358, \mathrm{P}=0.042 ;{ }^{\mathrm{b}} \chi^{2}=7.855, \mathrm{P}=0.005$

Table III. Comparison of LH, FSH level and FSH/LH ratio among the different Trp8Arg mutation genotypes.

\begin{tabular}{lrccc}
\hline Genotype & \multicolumn{1}{c}{$\mathrm{n}$} & FSH (IU/l) & LH (IU/l) & FSH/LH \\
\hline Arg/Arg & 5 & $6.15 \pm 0.55$ & $20.54 \pm 1.37$ & $0.300 \pm 0.03$ \\
Arg/Trp & 15 & $5.68 \pm 0.88$ & $18.12 \pm 2.14$ & $0.321 \pm 0.08$ \\
Trp/Trp & 100 & $6.13 \pm 1.74$ & $16.62 \pm 3.46^{\mathrm{a}}$ & $0.380 \pm 0.14$ \\
F & & 0.500 & 4.448 & 2.445 \\
P & & 0.608 & 0.014 & 0.091 \\
\hline
\end{tabular}

${ }^{\mathrm{a}} \mathrm{P}<0.05$ vs. the genotype of $\mathrm{Arg} / \mathrm{Arg}$.

Table IV. Comparison of LH, FSH level and FSH/LH ratio among the different Ile15Thr mutation genotypes.

\begin{tabular}{lrccc}
\hline Genotype & $\mathrm{n}$ & FSH (IU/l) & LH (IU/l) & FSH/LH \\
\hline Thr/Thr & 3 & $6.36 \pm 0.45$ & $21.07 \pm 1.22$ & $0.30 \pm 0.04$ \\
Ile/Thr & 14 & $5.93 \pm 0.91$ & $18.51 \pm 2.12$ & $0.33 \pm 0.07$ \\
Ile/Ile & 103 & $6.08 \pm 1.72$ & $16.65 \pm 3.43^{\mathrm{a}}$ & $0.38 \pm 0.14$ \\
F & & 0.105 & 4.394 & 1.573 \\
P & & 0.901 & 0.014 & 0.212 \\
\hline
\end{tabular}

${ }^{\mathrm{a}} \mathrm{P}<0.05$ vs. the genotype of Thr/Thr.

determines the antigenicity and its physiological function, it only presents its bioactivity after formation of a complete heterodimer through non-covalent bonding with the $\alpha$ subunit (8). The molecular weight of LH is $29.4 \mathrm{kDa}$. Its $\alpha$ subunit is composed of 92 amino acids with molecular weight of 14.6 kDa, and its $\beta$ subunit is composed of 112-114 amino acids with a molecular weight of $14.8 \mathrm{kDa}$. The structure and function of LH are similar to human chorionic gonadotropin, as the two hormones employ the same receptor (9).

The LH- $\beta$ subunit is encoded by a single gene that is located on chromosome 19q13.3. Its overall length is $1.65 \mathrm{~kb}$ and consists of three exons with 2 missense $\mathrm{T} \sim \mathrm{C}$ mutations at 
different locations in the 2nd exon. The first missense mutation can replace the 8th codon encoding the product tryptophan (Trp) to arginine (Arg), and the second missense mutation can replace the 158th codon encoding product isoleucine (Ile) to threonine (Thr) (10). The LH- $\beta$ gene has a variety of mutations that may lead to luteal phase deficiency symptoms, such as anovulation, inadequate luteal phase and immature follicle rupture. These symptoms contribute to menstrual disorders, polycystic ovarian syndrome, frequent miscarriage and infertility. The mechanism of these effects are unknown, but may relate to the incapacity of mutated LH to normally interact with its receptors (11).

Trp8Arg and Ile15Thr are LH- $\beta$ subunit gene mutations found in females, usually occurring simultaneously (12). Suganuma et al (13) found that mutations of Trp8Arg and Ile15Thr of the LH- $\beta$ gene may be related to menstrual disorders and menstrual disease in females. The Trp8Arg mutation produces an extra glycosylation signal in the LH- $\beta$ chain that promotes the number 13 codon Ans to produce an oligosaccharide side chain (Asn-X-Thr), leading to changes in structure and function of the LH- $\beta$ subunit. Takahashi et al (14) showed that Trp8Arg and Ile15Thr mutations were closely correlated with polycystic ovarian syndrome in Japanese women. The typical function of LH is responsible for ovarian and testicular circulation. Gonadal tissues in these two organs, such as membrane, granulosa and luteal cells of the ovary, have a high density of LH receptors. It is believed that these receptors on the cell membrane are common, yet LH receptors on granulosa cells are essential for the follicular maturation process, and LH receptors in luteal cells will increase during luteal growth and decrease during luteal degradation (15).

LH plays an important role in ovulation and the synthesis of ovarian hormones. In the normal menstrual cycle, the follicle may rupture and ovulation begins $24 \mathrm{~h}$ after the peak LH level. The primary function of this peak in LH is to promote recovery of oocyte meiosis and granulosa cell differentiation, to inhibit granulosa cell proliferation and to induce ovulation. However, the effect of LH on ovum development in the follicular phase is unclear (16).

Results from this study revealed that the allele frequency and genotype frequency of LH- $\beta$ subunit gene mutations Trp8Arg and Ile15Thr were significantly different between infertile women and healthy women. In addition, LH levels significantly differed among women of different genotypes, with the highest LH level in women with both mutations. However, FSH and the FSH/LH ratios were not significantly different. Results suggest that mutations in LH- $\beta$ subunit Trp8Arg and Ile15Thr correlate with female infertility and may be a risk factor for female infertility. The mechanism(s) of the effect are possibly related to the inability of mutated LH to bind normally with LH receptors. This effect may reduce LH-related biological effects, such as follicle growth and development. However, the potential mechanisms require further study.

\section{References}

1. Fazleabas AT: Physiology and pathology of implantation in the human and nonhuman primate. Semin Reprod Med 25: 405-409, 2007.

2. Romero Ramos R, Romero Gutiérrez G, Abortes Monroy I and Medina Sánchez HG: Risk factors associated to female infertility. Ginecol Obstet Mex 76: 717-721, 2008.

3. Menon KM, Nair AK, Wang L and Peegel H: Regulation of luteinizing hormone receptor mRNA expression by a specific RNA binding protein in the ovary. Mol Cell Endocrinol 260: 109-116, 2007.

4. Takahashi K, Kurioka H, Ozaki T, Kanasaki H, Kohsaka M, Miyazaki K and Karino K: Increased prevalence of luteinizing hormone beta-subunit variant in Japanese infertility patients. Hum Reprod 13: 3338-3344, 1998.

5. Liao WX, Roy AC, Chan C, Arulkumaran S and Ratnam SS: A new molecular variant of luteinizing hormone associated with female infertility. Fertil Steril 69: 102-106, 1998.

6. Filicori M: The role of luteinizing hormone in folliculogenesis and ovulation induction. Fertil Steril 71: 405-414, 1999.

7. Vigo E, Roa J, López M, et al: Neuromedins as novel putative regulator of luteinizing hormone secretion. Endocrinology 148: 813-823, 2007.

8. Wu J, Xu B and Wang W: Effects of luteinizing hormone and follicle stimulating hormone on the developmental competence of porcine preantral follicle oocytes grown in vitro. J Assist Reprod Genet 24: 419-424, 2007

9. Weghofer A, Schnepf S, Barad D and Gleicher N: The impact of luteinizing hormone in assisted reproduction: a review. Curr Opin Obstet Gynecol 19: 253-257, 2007.

10. Melamed P, Zhu Y, Tan SH, Xie M and Koh M: Gonadotropinreleasing hormone activation of c-jun, but not early growth response factor-1, stimulates transcription of a luteinizing hormone beta-subunit gene. Endocrinology 147: 3598-3605, 2006.

11. Lofrano-Porto A, Barra GB, Giacomini LA, Nascimento PP, Latronico AC, Casulari LA and da Rocha Neves Fde A: Luteinizing hormone beta mutation and hypogonadism in men and women. N Engl J Med 357: 897-904, 2007.

12. Arnhold IJ, Lofrano-Porto A and Latronico AC: Inactivating mutations of luteinizing hormone beta-subunit or luteinizing hormone receptor cause oligo-amenorrhea and infertility in women. Horm Res 71: 75-82, 2009.

13. Suganuma N, Furui K, Furuhashi M, Asada Y, Kikkawa F and Tomoda Y: Screening of the mutations in luteinizing hormone beta-subunit in patients with menstrual disorders. Fertil Steril 63: 989-995, 1995.

14. Takahashi K, Ozaki T, Okada M, Kurioka H, Kanasaki H and Miyazaki K: Increased prevalence of luteinizing hormone betasubunit variant in patients with premature ovarian failure. Fertil Steril 71: 96-101, 1999.

15. Mafra FA, Bianco B, Christofolini DM, Souza AM, Zulli K and Barbosa CP: Luteinizing hormone beta-subunit gene (LHbeta) polymorphism in infertility and endometriosis-associated infertility. Eur J Obstet Gynecol Reprod Biol 151: 66-69, 2009.

16. Hsieh M, Lee D, Panigone S, Horner K, Chen R, Theologis A, Lee DC, Threadgill DW and Conti M: Luteinizing hormonedependent activation of the epidermal growth factor network is essential for ovulation. Mol Cell Biol 27: 1914-1924, 2007. 